\title{
Utilization and Bioactivity of Java Long Pepper (Piper retrofractum Vahl) for Education Purposes
}

\author{
Marina Silalahi \\ Biology of Education, Fakultas Keguruan dan Ilmu Pendidikan, Universitas Kristen Indonesia, Cawang, Jakarta \\ Timur \\ E-Mail: marina.silalahi@uki.ac.id
}

\begin{abstract}
Piper retrofractum (PR) or also known as Javanese chili has long been used as a spice and medicine. Bioactivity of plants as medicinal ingredients is related to secondary metabolites compounds. The writing of this article is based on a literature review of various scientific journals, books and other research results then synthesized so as to obtain comprehensive information about the benefits and bioactivity of PR. Wild type of PR is found in Asia especially Thailand, Indo-China, Malaysia, Maluku. The ethnics uses the PR as traditional medicine to cure of digestive disorders, blood circulation, asthma, influenza, rheumatism, and hypertension. The PR has activities as anti-cancer, anti-obesity, anti- diabetes mellitus, anti-oxidants and aphrodisiac. The active compounds of PB is alkaloids, especially piperine, piperlongumine and pipelartine. The potential of $\mathrm{PB}$ as aphrodisiac needs to be investigated further to minimize toxicity and fixed dose.
\end{abstract}

Keywords: Java long pepper, aphrodisiac, piperine, Piper retrofractum

\section{INTRODUCTION}

Java chili or Piper retrofractum (PR) is one type of spice used as a spice in cooking and traditional medicine. The naming of Java chili (PB) is thought to be related to the shape of the fruit which is similar to chilli (Capsicum sp.) And is found in the forests of Java, even though the taxonomy is very much different. Silalahi et al (2015b) stated that by traders of medicinal plants in Kabanjahe, PB is known by the local name of single pepper and is used as traditional medicine. PR and pepper (Piper nigrum) are aromatic herbs but PR has a sharper aroma compared to P. nigrum (Utami and Jansen 1999), besides pepper is more widely used as a cooking spice while PB is better known as a drug.

Utilization of PB as a drug is suspected since thousands of years ago. This is evident from traditional medical manuscripts that have been recorded in Ayurveda in India (Chaveerach et al 2006), Trickatu in Thailand (Chaveerach et al 2006), and Lontar Husada Indonesia (Suryadharma 2010) which have listed PB as traditional medicine. In medicine in Thailand, Trikatu means "three hot items" consisting of Piper nigrum, PR and Zingiber sp. Chaveerach et al (2006) Tricks are used to increase the absorption of food nutrients, antitussive, diaphoretic, influenza and flatulence.
PR fruit has a "hot" taste so that in traditional medicine it is used to treat digestive disorders, improve blood circulation, asthma, influenza, hypertension, antiflatulent (Chaveerach et al 2006), intestinal disorders, accelerate placental puputage, bleeding, irritation, colic (Utami and Jansen 1999). Homework together with Piper logum is used as a spice in various dishes such as pickles, and karri, and food preservatives (Utami and Jansen 1999). In Indonesia the leaves are used to wash the mouth and additives to toothpaste (Utami and Jansen 1999). Karo PB is used by people to overcome heart problems, increase stamina and overcome rheumatism (Silalahi et al 2015b).

PR has been widely cultivated in the yard (Silalahi 2015; Silalahi 2019) and is also traded on the market (Silalahi et al 2015b) so as to facilitate access to its acquisition. Utami and Jansen (1999) stated that Indonesia is one of the exporting countries of PR to Peninsular Malaysia, Singapore, China, Europe, and the United States as spices. Therefore, PR cultivation has a double effect, in addition to being a drug, it can also be a source of additional income.

Utilization of plants as medicine is related to the content of secondary metabolites or often also referred to as bioactive compounds. PR contains piperine, resin, 
fiber, starch, and essential oil (Utami and Jansen 1999). Pillai et al. (2000) states that PB contains volatile oil (1.5\%), fixed oil $(6.6 \%)$ and piperine (4.5\%). Studies on the relationship between PB utilization and bioactivity have been carried out, but most only discuss trade and secondary metabolites. This article will discuss the relationship of secondary metabolites with PB utilization, so that it can be used as a reference for further utilization.

\section{METHODS}

The writing of this article is based on a literature review of various books, articles and other research results. Literature obtained online is obtained at google schoolar, scopus, using keywords including Piper retrofractum, botany of PR, bioactivity of PR. All literature obtained was synthesized so as to obtain comprehensive information about the use and bioactivity of public relations.

\section{RESULT AND DISCUSSION}

\subsection{Botany of Piper retrofractum}

The Piper genus is estimated to have around 1200 species distributed in the pantropical area and most of them are found in neotropics and around 400 species are found in the Malesiana area. One of the species of Piper that is used as a drug is Piper retrofractum and in Indonesia has been widely cultivated (Silalahi 2015). The wild form of PR is found in Thailand, Indo-China, Malaysia, Maluku but its semi-wild is found in the Ryukyu Islands and has been cultivated in Semenajung Malaysia (Utami dan Jansen 1999).

Piper retrofractum Vahl sinonim with $\mathrm{P}$. chaba Hunter, Chavica retrofracta (Vahl. Miq.), Piper officinarum (Mig.) C. DC. (Utami dan Jansen 1999). Chaveerach et al (2006) stated Piper longum Linn sinonin dengan PR, P. sarmentosum Wall., P. latifolium Hunter, P. turbinarium Noronha., Chavica roxburghii Miq., C. sarmentosa Miq. Piper peepuloides Wall, Syn. Chavica peepuloides Miq. Piper retrofractum Vahl., P. chaba Hunt (Chaveerach et al 2006). Utami and Jansen (1999) distinguish between P. longum and PR. P. longum is known as Indian long pepper, while PR is known as Java long pepper. This shows that there are still differences in the naming of Java chili. Vernaculer name PR is Javanese long pepper (Inggris), Poivre long de Java (Francis), cabe jawa (Indonesia pada umumnya), lada panjang (Sumatera), cabia (Sulawesi), chabai Jawa, bakek, kedawak (Malyasia), litlit (Tagalog), amaras (Iloko), dipli (Thailand), dipli-chuak
(Penisular) (Utami dan Jansen 1999), lada tunggal (Batak) (Silalahi 2014).
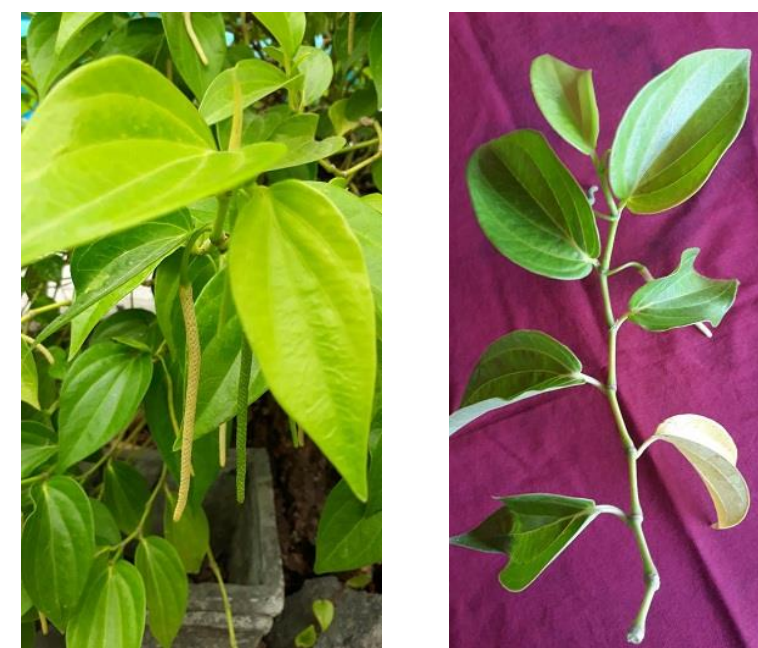

Figure 1. Piper retrofractum. A. Habitus, B. Branch.

Piper retrofractum is a chronic herb with soft stems and bifus (dioseus). These plants creep or creep with additional roots and their height can reach $10 \mathrm{~m}$ (Figure 1A). The petiole is $0.5-3 \mathrm{~cm}$ long with ovate to oblong leaf pieces measuring $8-20 \mathrm{~cm} \mathrm{x} \mathrm{3-13} \mathrm{cm} \mathrm{(Figure} \mathrm{1B).}$ The basal part of the leaf is cordate, obtuse or cuneate with the apex of the leaf being tepering or acuminate (Figure 1C). Flower shaped upright spica with peduncula length 1-2 $\mathrm{cm}$ (Figure 1C and D). Bractaia ovate widens $1-2 \mathrm{~mm}$ in length. The male spica has a length of $2.5-8.5 \mathrm{~cm}$, with a number of stems $2-3$ very short. Female spica with a length of $2-3 \mathrm{~cm}$ with $2-3$ stigma is very short and persistent (Figure 1D). Cylindrical fruit with size 2-4 cum $x$ 4-8 $\mathrm{mm}$. The berry-shaped fruit with a stalk sits on bractea, hard with a sharp aroma when green and becomes soft and sweet and becomes red when ripe. Glabose seeds with a diameter of 2-2.5 mm, white and fleshy inside (Utami and Jansen 1999; Chaveerach et al 2006; Babu et al 2006). P. longum has smaller and more spicy fruits than Java chili (P. retrofractum). The P. retrofractum spike is conical while the P. longum is cylindrical (Babu et al 2006). 

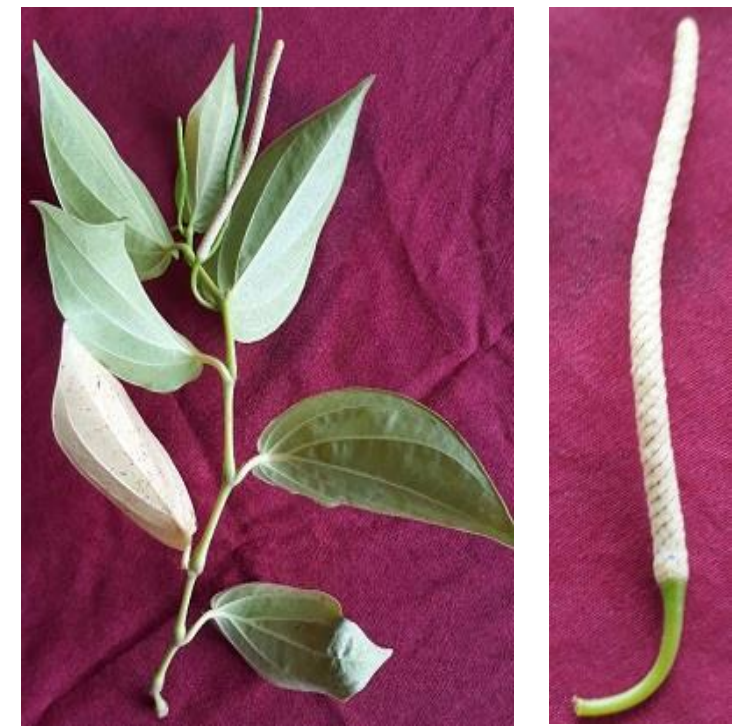

Figure 1. Piper retrofractum. C. Branch with old and young fruit, D. Mature fruit.

\subsection{Secondary Metabolism}

Secondary metabolites are compounds that are synthesized by plants through secondary metabolic processes. When compared with primary metabolites, the levels are much smaller but very important in the process of defense against the environment (Pillai et al. 2000). The Piper genus is widely known to produce secondary metabolites in the form of essential oil or volatile oil (Hao et al 2018). Volatile oil compounds are volatile compounds at room temperature, thus giving a distinctive aroma to plants and are often used as plant characters.

Volatile oil compounds produced by plants vary depending on origin, age and habitat. Volatile compounds from 10 Piper species cultivated on Hainan Island include benzaldehyde, cinnamaldehyde, $\beta$ caryophyllene, ocimene, lavandulol, myrcene, cubebene, terpinene, linalool, $\alpha$-caryophyllene, $\beta$ caryophyllene, ocimene, lavandulol, myrcene, cubebene, terpinene, linalool, $\alpha$-caryophyllene, $\beta$ caryophyllene, ocimene, lavandulol, myrcene, cubebene, terpinene, linalool, $\alpha$-caryophyllene, $\beta$ caryophyllene, ocimene, lavandulol, myrcene, cubebene, terpinene, linalool, $\alpha$-caryophyllene, $\beta$ caryophyllene, ocimene, lavandulol, myrcene, cubebene, terpinene, linalool, $\alpha$-caryophyllene, $\beta$ elements Furthermore, Hao et al (2018) stated that P. retrofractum contains ocimene $(15.6 \%)$, linalool (12.9\%), $\alpha$-caryophyllene $(9.61 \%)$, and germacrene D $(7.15 \%)$, linalool $(12.9 \%)$ ), and trans-hex-3-en-1-ol (1.78\%), octyl salicylate $(0.34 \%)$, catechol $(2.48 \%)$, and 2-octaneone (0.29\%) (Hao et al. 2018).
Empirically, PB has a spicy taste derived from secondary metabolism, piperin, piperlongumine (present in the main alkaloid other than piperin) and pipelartin (Pillai et al. 2000).

\subsection{Uses}

\subsubsection{Anticancer}

Cancer is a deadly disease that ranks second after heart disease (Mulia 2016). Cancer is often associated with the presence of free radicals, therefore anti-free radical compounds, also known as anti-oxidants and potentially as anti-cancer (Mulia 2016). Plants used as cancer drugs are plants that produce compounds that are antiproliferation of cells (Munin and Hanani 2011). The ability of PR as an anti-cancer has been reported by Bidarisugma et al (2011), Mulia (2016) and Ekowati et al (2012).

Piper retrofractum has been reported to have antioral cancer activity (Bidarisugma et al 2011) and other types of cancer. The ability of PR as an anti-cancer is associated with the content of piperin and piplartin which have activities that inhibit the proliferation of cancer cells (Bidarisugma et al 2011). Piperin also works synergistically with other bioactive substances such as capsaicin and curcumin. The anti-tumor activity of piplartin is related to the inhibition of the rate of cell proliferation, in terms of the reduction of $\mathrm{Ki} 67$, namely antigens in the cell nucleus associated with G1, S, G2, and $\mathrm{M}$ in the cell synthesis cycle. In its mechanism of action piplartin will further increase its antiproliferative activity if it is synergized with piperine (Bidarisugma et al 2011). Zingiber officinale (ZO), Piper retrofractum, and combinations show cytotoxic activity, induced apoptosis, and p53 expression from HeLa, T47D, and MCF-7 cell lines (Ekowati et al 2012). The combination of $\mathrm{ZO}, \mathrm{PR}$, and $\mathrm{ZO}+\mathrm{PR}$ has cytotoxic activity in Myeloma cells with IC50 of 28, 36 , and $55 \mathrm{mg} / \mathrm{ml}$ and in mouse cells and IC50 apoptotic activity, and increased expression of p53 in Myeloma and WiDr cells respectively 74, 158 and 64 $\mathrm{mg} / \mathrm{ml}$, respectively (Ekowati et al 2012).

\subsubsection{Antioxidants}

Antioxidants are compounds that can inhibit free radicals. Secondary metabolites that function as antioxidants are associated with phenolic content. Piperin and piplartin function as antioxidants that can protect body cells from free radical damage (Bidarisugma et al 2011). PR extracted with different solvents (methanol, ethyl acetate, $\mathrm{n}$ hexane) has 
antioxidant activity tested with 2,2-diphenyl-1picrylhydrazyl (DPPH) (Jadid et al 2016). IC50 values for DPPH radicals with methanol, ethyl acetate and nhexane extract from PR were found 101.74; 66.12 and $57.66 \mathrm{ppm}$ respectively. Interestingly, the IC50 value of $\mathrm{n}$-hexane extract $(57.66 \mathrm{ppm})$ is lower than ascorbic acid (66.12) ppm), indicating that $\mathrm{n}$-hexane extract is a free radical scavenger that is stronger than methanol and ethyl acetate extract (Jadid et al 2016).

\subsubsection{Anti-Obesity}

PR significantly reduces body weight and fat in obese-induced animals after long-term use, as well as to reduce blood glucose and insulin levels in these animals, thereby demonstrating anti-diabetic effects (Kim et al 2017). PR has weight loss and body fat activity caused by the activation of UCP thermogenesis, prophylaxis and diabetes therapy by reducing fasting glucose levels and blood insulin levels, and increased muscle mass and exercise performance by inhibition of ACC and CPT-1 activation driven by AMPK activity (Kim et al 2017).

\subsubsection{Aphrodisiac}

More than $10 \%$ of married men in Indonesia suffer from erectile dysfunction. Generally, erectile dysfunction occurs in men aged around 40 years. PR has long been known as one of the Indonesian traditional medicines that can be used to increase stamina. Aphrodisiac effects that can improve the sexual function of $\mathrm{PR}$ are derived from piperine alkaloids, ethanol, and essential oils contained which have androgenic and anabolic effects and increase blood circulation so that it has the potential to overcome erectile dysfunction problems (Dinanti 2011)

Aphrodisiac is a compound used to increase sexual arousal. Rahmawati and Bachri (2012) stated that PR has aphrodisiac activity with additional ingredients Centella asiatica and temulawak (Curcuma domestica). Infusion PR, Centella asiatica, and Curcuma domestica with a dose of $2.1 \mathrm{mg} / 10$ grams of body weight have androgenic and anabolic effects. The main alkaloid in fruit PR which is thought to be an active compound with aphrodisiac properties is piperin. Some parameters used to determine sexual arousal in experimental rats include frequency of introduction, climbing, coitus, testosterone levels (Rahmawati, dan Bachri 2012).

Exogenous androgens can increase blood testosterone levels and suppress the production of follicle stimulating hormone (FSH) and luteinizing hormone (LH) in hypogonadic men. PR is a natural androgen that has been widely used by humans. PR can increase blood testosterone levels in 7 of 9 hypogonadic men (78\%), PR extracts dose of $100 \mathrm{mg} /$ day cannot reduce $\mathrm{FSH}$ and LH levels in hypogonadic men, against PSA and hypogonadal male body weight, are androgenic is weak and can increase the frequency of hypogonadal male coitus. PR extract at a dose of 100 mg / day can be / act as androgenic phytopharmaca which can increase blood testosterone and libido levels in male hypogonads and be safe (Moeloek et al 2010).

\section{CONCLUSIONS}

The PR has activities as anti-cancer, anti-obesity, anti-diabetes mellitus, anti-oxidants and aphrodisiac. The active compounds of PR is alkaloids, especially piperine, piperlongumine and pipelartine. The potential of PR as aphrodisiac needs to be investigated further to minimize toxicity and fixed dose.

\section{REFERENCES}

1. Babu, K.N., Divakaran, M., Ravindran, P.N., Peter K.V., 2006. Long pepper Dalam Handbook of herbs and spices Volume 3 Edited by K. V. Peter Woodhead Publishing Limited, Abington Hall, Abington Cambridge CB1 6AH, England. 2006: 420-438.

2. Bidarisugma, B., Sholikhah, M., Balbeid, S.U., Irmawati, A., 2011. Piperin and piplartin as natural oral anticancer drug . Dent. J. (Maj. Ked. Gigi) 44(4): 215-219.

3. Chaveerach, A., Tanee, T., Sanubol, A., Monkheang, P., Sudmoon, R. 2016. Efficient DNA barcode regions for classifying Piper species (Piperaceae). PhytoKeys 70: 1-10.

4. Chaveerach, A., Mokkamul, P., Sudmoon, R., Tanee, T., 2006. Ethnobotany of the genus Piper (Piperaceae) in Thailand. Ethnobotany Research \& Applications 4: 223-231.

5. Dinanti, B.R., 2014. Long pepper (Piper retrofractum Vahl) to overcome erectile dysfunction. J Majority 3(7): 1-7.

6. Ekowati, H., Achmad, A., Prasasti, E., Wasito, H., Sri, K., Hidayati, Z., Ekasari, T., 2012. Zingiber officinale, Piper retrofractum and combination induced apoptosis and p53 Expression in Myeloma and WiDr Cell Lines. Hayati Journal of Biosciences 19(3): 137-140

7. Hao, C.Y., Fana, R., Qin, X.W., Hu, L.S., Tan, L.H., Xu, F., Wu, B. 2018. Characterization of volatile compounds in ten Piper species cultivated in Hainan Island, South China. International Journal of Food Properties 21(1): 633-644. 
8. Jadid, N., Hidayati, D., Hartanti, S.R., Arraniry, B.A., Rachman, R.Y., Wikanta, W., 2016. Antioxidant activities of different solvent extracts of Piper retrofractum Vahl. using DPPH Assay. Proceeding of International Biology Conference 2016 AIP Conf. Proc. 1854, 020019-1-020019-6; doi: 10.1063/1.4985410. Published by AIP Publishing.

9. Kim, K.Y., Kim, M.S., Hwang, J.K., Goyang-Si. 2017. Composition for treating obesty and dabetes and for increasing muscle mass and improving capacity for exercise, comprising extracts of Piper retrofractum Vahl. fruits as active ingredients. Patent Application Publication (10) Pub. No.: US 2017/0209511 A1 (43) Pub. Date: Jul. 27, 2017

10. Moeloek, N., Lestari, S.W., Yurnadi, Wahjoedi, B. 2010. Uji klinik ekstrak cabe jawa (Piper 14.

15. Silalahi, M. 2014. The ethnomedi-cine of the medicinal plants in sub-ethnic Batak, North Sumatra and the conser-vation perspective, disserta-tion. Indonesia: Universitas Indonesia. p. 140.

16. Silalahi, M., Nisyawati, Walujo, E.B., Supriatna, J., Mangunwardoyo, W., 2015. The local knowledge of medicinal plants trader and diversity of medicinal plants in the Kabanjahe traditional market, North Sumatra, Indonesia. Journal of Ethnopharmacology 175: 432-443.

17. Silalahi, M. 2015. Pengetahuan Mahasiswa Prodi Pendidikan Biologi FKIP UKI terhadap Keanekaragaman Tumbuhan di Lingkungan Kampus Universitas Kristen Indonesia Cawang, Jakarta Timur Sebagai Langkah Awal untuk Mewujudkan Green Campus. Laporan Penelitian retrofractum Vahl) sebagai fitofarmaka androgenik pada laki-laki hipogonad. Maj Kedokt Indon 60(6): 255-262

11. Mulia, K., Hasan, A.E.Z., Suryani., 2016. Total phenolic, anticancer and antioxidant activity of ethanol extract of Piper retrofractum Vahl from Pamekasan and Karang Asem. Curr. Biochem. 3(2): 80- 90

12. Munim, A., Hanani, E., 2011. Fisioterapi dasar. Dian Rakyat. Jakarta: viii $+356 \mathrm{hlm}$.

13. Rahmawati, N., Bachri, M.S. 2012. The aphrodisiac effect and toxicity of combination Piper retrofractum L, Centella asiatica, and Curcuma domestica infusion. Health Science Indones 3(1): 19-22.

Prodi Pendidikan Biologi Universitas Kristen Indonesia, Jakarta.

18. Silalahi, M., 2019. Keanekaragaman tumbuhan bermanfaat di pekarangan oleh Etnis Sunda Di Desa Sindang Jaya Kabupaten Cianjur Jawa Barat. Jurnal Pendidikan Matematika dan IPA 10(1): 88104.

19. Suryadarma, I.G.P., 2010. Keanekaragaman tumbuhan bahan kebugaran dalam naskah Lontar Rukmini Tatwa masyarakat Bali. Biota 15(2): 294305 .

20. Utami, D., Jansen, P.C.M., 1999. Piper L. in de Guzman CC and Siemonsma (Editors) 1999. Plant Resources of South-East Asia No 13. Spices. Backhyus Publisher, Leiden, the Netherland, P 183-188 